\title{
Livelihood Challenges of Adjacent Communities of Selected National Parks in West Africa
}

\author{
Folusade Catherine Arowosafe \\ Department of Ecotourism and Wildlife Management, \\ Federal University of Technology, Akure, Nigeria \\ Adebayo Adewunmi Emmanuel \\ Department of Urban and Regional Planning, \\ Federal University of Technology, Akure, Nigeria
}

\begin{abstract}
The livelihood challenges of communities adjacent to Kainji Lake and Mole National Parks in Nigeria and Ghana respectively were studied. This was intended to underscore the concept of Sustainable Livelihood in poverty alleviation. Survey design was employed using semi-structured questionnaire, Focus Group Discussion and Key Informant Interview to gather data from 582 residents of 20 communities adjacent to both Parks. Descriptive and inferential statistics were used for data analysis. Results obtained show that the major livelihood activities at adjacent communities of both Parks were crop and livestock farming. Some livelihood challenges encountered at the communities include destruction of crops by wild animals, reduced access to farmlands, and exclusion from use of natural resources. Chi-squared analysis also reveals a significant difference between the challenges encountered at the adjacent communities to both Parks. To reduce the adverse effects of the Parks on the communities, compensation for damages, further collaboration with NGOs to provide infrastructure, and training on alternative sources of livelihood are recommended.
\end{abstract}

Keywords: adjacent community; ecotourism; Ghana; Nigeria; livelihood challenges; national parks.

\section{INTRODUCTION}

The establishment of protected areas is one of the strategies designed to restore balance between humans and their environment [1]. Most protected areas, especially National Parks, are potential areas for the development of ecotourism because of the abundant biodiversity, landscapes and the cultural heritage of local or indigenous residents [2]. These ecotourism development and activities can be important sources of economic diversification and livelihood opportunities [3]. The establishment of Protected Areas signifies one of the key strategies for biodiversity conservation. However, their ability to improve the livelihood of adjoining communities remains a source of increasing controversy [4].

According to Neth [5], ecotourism development is based on growing social conflicts, rapid natural resource depletion, inadequate government funding for the management of Protected Areas, increasing dependency on external aids, and the need for economic growth and poverty reduction. Its main objectives are to alleviate environmental problems, improve conservation and natural resource management, as well as reduce poverty by improving livelihoods in rural communities. 
The livelihood activities of rural communities are of different forms with many households taking up various activities to enable them contribute to family needs. Many of these activities however rely on the use of natural resources many of which are found within the National Parks. Therefore, the way in which tourism complements or conflicts with existing activities has emerged as a key theme in community and household discussions [6]. Though seen as a chance for an additional activity to combine with existing livelihood activities (not as a substitute), it is equally perceived as a risky business.

According to Ijeomah [7], a livelihood is sustainable when it can cope with and recover from stresses and shocks and maintain or enhance its capabilities and assets both now and in the future, while not undermining the natural resource base. Local people have complex livelihood strategies (due to multiple land uses and diversification of risks across several activities) which are affected by tourism in many different ways, positively and negatively, directly and indirectly [8]. Different people have different livelihood priorities and different types of community tourism ventures have different kinds of impacts. This touches on their survival, as access to food, water, shelter and other basic necessities are involved.

Common tourism case studies around the world often portray negative picture of local people being disenfranchised from their resources. There are numerous of such examples in Kenya, Namibia and Tanzania where foreign tourism operators simply established camps or lodges in communal areas, often near a major water resource (spring or river); leading to various forms of pollution and disruption of ecological systems. Kamuaro [9] reported that the sewage material from one Ngorongoro hotel is dumped at a 'safe' distance from one of the tourist hotels and allowed to flow into neighbouring grazing grounds and Masai settlement area. In other parts, sewage material from camp sites is simply thrown into the river from which wildlife, livestock and local communities draw water. With the establishment of tourism in these areas, local people often illegally lose their homes and livelihood mostly without compensation. They are pushed into marginal lands with harsh climatic condition, poor soil, lack of water resources and infested with human and livestock diseases making survival impossible.

There are also several contrasting positive examples where ecotourism has sustainably empowered individuals, households and communities, and ecotourism projects have been heavily dependent on local consultation as it is in The Gambia, Bhaktapur in Nepal, Kunene and Caprivi in Namibia [10-16]. These positive impacts have become so publicised that tourism is being adopted as an instrument for economic development and poverty alleviation in many countries.

Tourism has been a growing industry in both Nigeria and Ghana's economy, accounting for as much as 7.9 per cent of Ghana's GDP in 2014 [17-18]. It is true that numerous National Parks have been established all over the world to protect nature, but this has brought several social consequences on the neighbouring communities. Numerous researches have been carried out to examine conservation, ecotourism development and community participation in National parks in Nigeria, Ghana and other countries [19-23]. Some studies have been carried out to compare perceptions of local residents on the impact of tourism on their communities based on studies of two National Parks within the same country or area [24]. However, few studies have been carried out to assess and compare the perception of challenges encountered in adjacent communities of National Parks beyond specific national boundaries. This study addresses the critical need to investigate the challenges to livelihoods of residents within 
adjacent communities of National Parks, though exploring the particular experiences around two notable Parks in West Africa.

\section{MATERIALS AND METHODS}

This study covers two National Parks in West Africa namely Kainji Lake National Park, which is the first National Park and the second largest park in Nigeria and Mole National Park which is the largest park in Ghana. The two National Parks are in category II according to the categorization of International Union for the Conservation of Nature (IUCN). Kainji Lake National Park was established in 1979 by the merger of two non-contiguous sectors; the Zugurma Sector $\left(1,370 \mathrm{~km}^{2}\right)$ and Borgu Sector $\left(3,970 \mathrm{~km}^{2}\right)$. Kainji Lake National Park is located on the boundary between the north of the Guinea Savannah and south of the Sudan Savannah vegetation zones, which are rich in biodiversity of plant and animal species. It is located within latitudes $9^{0} 40^{\prime}$ and $10^{\circ} 30^{\prime}$ North and longitudes $3^{\circ} 30^{\prime}$ and $5^{\circ} 50^{\prime}$ West and has a total land mass of $5,340.82 \mathrm{~km}^{2}$.

Mole National Park is Ghana's largest protected area by world data on Protected Areas [25]. The Park is located in Northwest Ghana on grassland savanna and riparian ecosystems at an elevation of 150metres with sharp escarpment forming the southern boundary of the Park. It is situated between Wa and Tamale and lies within latitudes $9^{0} 11^{\prime}$ and $10^{0} 10^{\prime}$ North and longitudes $1^{0} 22^{\prime}$ and $2^{0} 13^{\prime}$ 'West (Mole National Park, 2011). It was gazetted as a National Park in 1971 under the Wildlife Reserve Regulations for its outstanding wildlife and also to protect its habitat. Its area was enlarged to $4,554 \mathrm{~km}^{2}$ by extending the boundaries northward to the Kulpawn River and eastward over the Konkori escarpment. In 1992, the Park was further enlarged to its present size of about $4,577 \mathrm{~km}^{2}$ with the addition of the Gbantala triangle.

Based on accessibility and proximity of the adjacent communities to the two National Parks, ten communities were purposively selected from each of Kainji Lake and Mole National Parks. The communities sampled at each of the National Parks represented more than $30 \%$ of the total communities adjacent to the Parks, a percentage which is representative of the existing communities [26]. The communities selected at Kainji National Park are Wawa, Leshigbe, Mallale, GadaOli, Fellegi, Pataiko, Worumakoto, Kemenji, Ibbi and New Kali. At Mole National Park, the selected communities include Larabanga, Kpulumbo, Yazouri, Mognori, Murugu, Kaden, Kananto, Grupe, Bawena and Kabampe. Inventory of households was taken in the selected communities using target audience who were familiar with the communities, as applied by Ijeomah et al [27]. The community register was equally available for use. A number of respondents in each household and community were selected as described by Akwotugu [28] using stratified random sampling.

A total of 582 respondents were sampled for the administration of 305 copies of a validated semi-structured questionnaire at the selected adjacent communities of Kainji Lake National Park and 277 copies at Mole National Park. The difference was based on the number of large households found in two of the selected communities of Kainji Lake National Park, unlike Mole National Park which had only one community with large households. All the administered copies of the questionnaire (100\%) were retrieved and used in data analysis. Key Informants Interviews were conducted to gather primary information from village heads of selected communities. Focused group meetings were organised as a follow up to the Key Informant Interviews. The issues raised by the key informants were discussed at the group level. The participants for the focused group meetings were separated into male and female groups to 
allow the female participants to freely express themselves. Each group comprised 6 to 8 participants for effective discussion.

\section{RESULTS \\ Socio-demographic Characteristics of Respondents}

Findings on the socio-demographic characteristics are shown on Table 1. It was found that there were more male respondents than females at the two National Parks. At Kainji Lake National Park communities, findings show that $61.6 \%$ of the respondents were males while $38.4 \%$ of the respondents were females. At Mole communities, $64.3 \%$ of the respondents were males and $35.7 \%$ were females, indicating that more females (38.4\%) were sampled at Kainji than at Mole communities (35.7\%). Also shown in the result was that the highest age incidence at both parks occurred in the age range of 30-39years, with 39\% for Kainji Lake National Park and $34.7 \%$ for Mole National Park communities. There were more married respondents at the two National Parks than the unmarried respondents with $82.6 \%$ married respondents at Kainji, and $85.5 \%$ married respondents at Mole.

On education, majority of the respondents had no formal education. The result reveals that $65.5 \%$ of respondents at Kainji had no formal education, while $74.4 \%$ respondents at Mole had no formal education. The largest household size at communities around Kainji Lake National Park was found in the range of 6-10, adding up to $42.6 \%$, while the largest household size at communities around Mole Park was 11-15 representing 40.5\%. The highest incidence of household size is observed at Kainji National Park. The result obtained for livelihood activities of adjacent communities revealed that the highest percentage of respondents at both National Parks were farmers with Mole National Park having a relatively higher percentage. Very few respondents were engaged in fishing at Kainji (2\%) and Mole (1.1\%), but quite a number were traders at Kainji (23.9\%) with relatively lower percentage at Mole (15.8\%). Some artisans were also found around the two communities. 
Table 1: Socio-demographic characteristics of communities from both parks

\begin{tabular}{|c|c|c|c|c|c|}
\hline \multirow[b]{2}{*}{$\begin{array}{l}\text { Demographic } \\
\text { Variables }\end{array}$} & & \multicolumn{2}{|c|}{ Kainji Lake National Park } & \multicolumn{2}{|c|}{ Mole National Park } \\
\hline & & $\begin{array}{l}\text { Frequency } \\
\text { (f) }\end{array}$ & $\begin{array}{l}\text { Percentage } \\
(\%)\end{array}$ & $\begin{array}{l}\text { Frequency } \\
\text { (f) }\end{array}$ & $\begin{array}{l}\text { Percentage } \\
(\%)\end{array}$ \\
\hline \multirow[t]{2}{*}{ Gender } & Male & 188 & 61.6 & 178 & 64.3 \\
\hline & Female & 117 & 38.4 & 99 & 35.7 \\
\hline \multirow[t]{5}{*}{ Age } & $18-29$ years & 84 & 27.5 & 47 & 17 \\
\hline & 30-39 years & 119 & 39 & 96 & 34.7 \\
\hline & $40-49$ years & 66 & 21.6 & 80 & 28.8 \\
\hline & $50-59$ years & 27 & 8.9 & 40 & 14.4 \\
\hline & Above 59 years & 9 & 3 & 14 & 5.1 \\
\hline \multirow[t]{4}{*}{ Marital Status } & Single & 49 & 16.1 & 36 & 13 \\
\hline & Married & 252 & 82.6 & 237 & 85.5 \\
\hline & Widowed & 4 & 1.3 & 3 & 1.1 \\
\hline & Others & 0 & 0 & 1 & 0.4 \\
\hline \multirow[t]{6}{*}{$\begin{array}{l}\text { Educational } \\
\text { status }\end{array}$} & No formal education & 200 & 65.6 & 206 & 74.4 \\
\hline & Primary education & 46 & 15.1 & 25 & 9 \\
\hline & Junior Sec. Education & 9 & 3 & 13 & 4.7 \\
\hline & Senior Sec. Education & 34 & 11.1 & 26 & 9.4 \\
\hline & Tertiary Education & 6 & 2 & 3 & 1.1 \\
\hline & Others & 10 & 3.3 & 4 & 1.4 \\
\hline \multirow[t]{5}{*}{ Household size } & $1-5$ & 6 & 2 & 5 & 1.8 \\
\hline & $6-10$ & 130 & 42.6 & 74 & 26.7 \\
\hline & $11-15$ & 117 & 38.4 & 113 & 40.8 \\
\hline & $16-20$ & 52 & 17 & 82 & 29.6 \\
\hline & above 20 & 0 & 0 & 3 & 1.1 \\
\hline \multirow[t]{6}{*}{$\begin{array}{l}\text { Livelihood } \\
\text { activities }\end{array}$} & Farming & 171 & 56.1 & 179 & 64.6 \\
\hline & Fishing & 6 & 2 & 3 & 1.1 \\
\hline & Trading & 73 & 23.9 & 44 & 15.8 \\
\hline & Formal employment & 14 & 4.6 & 8 & 2.9 \\
\hline & Artisanry & 36 & 11.8 & 29 & 10.5 \\
\hline & Others & 5 & 1.6 & 14 & 5.1 \\
\hline
\end{tabular}

Source: Authors' Fieldwork, 2016

\section{Results from Focus Group Discussion}

The discussion revealed that trading in the adjacent communities of Kainji and Mole National parks involved buying and selling of farm produce such as maize, rice, cassava, melon, groundnut, kulikuli, dawadawa and fish. Many of the women indicated that this was a main livelihood activity for them as many of them did not have access to farmlands. Some of the items sold include basic household needs like shea butter cream, soap, and cooked food (food vending). A few of the traders had shops where they displayed their goods while majority would sell in front of their houses or wait till the market day to sell their goods. The informal sector business thrived here. 
Those in formal employment in the adjacent communities of both parks consisted mainly of teachers, nurses and hospital attendants as well as local government civil service workers. Some of them also worked with private business owners as hotel staff, and as petrol station attendants especially at Wawa, a community at Kainji Lake National Park. Artisans at Kainji communities include blacksmiths as well as craftsmen and tool makers who engaged in carvings and making of crude agricultural tools such as hoes and cutlasses. At the communities adjacent to Mole National Park, it was discovered that basket weaving was a traditional livelihood activity in some of the communities, especially Kpulumbo and Mognore. Traditional cloth weaving was also identified as part of the livelihood activities of these communities.

Discussion and interviews further revealed that gathering of natural resources was important to the residents as they depended so much on the natural resources which could be found in the areas close to and within the National Parks. Most of the items gathered include firewood, spices, leaves, materials for weaving, shea butter nut and barks of trees. Others include dyeing materials, silk cotton materials, materials for carving, sand for plastering, and long grasses for roofing, fencing and broom making. Apart from the already mentioned livelihood activities, residents also engage in agricultural processing activities. Activities such as shea butter processing, garri processing, and milling activities were also carried out.

\section{Results from Questionnaire Administration}

The result of the livelihood challenges encountered by the residents of the communities adjacent to Kainji Lake and Mole National Parks is presented on Table 2. These challenges are reduced land for farming, exclusion from resource use, crop destruction by wild animals, insufficient infrastructural development, insufficient share of Park resources, lack of credit facilities, difficulty in transporting farm produce to market, lack of storage facilities as well as diseases and pest of crops and livestock. However, Kainji Lake National Park communities had lesser problem with reduced land for farming (38.4\%), when compared with Mole communities (54.7\%). Also, exclusion from resource use was higher at Mole $(51.8 \%)$ than at Kainji Lake communities (38.4\%).

Crop destruction caused by wild animals was higher at Kainji National Park communities $(65.7 \%)$ than at Mole communities with 51.5\%, while insufficient infrastructural development was higher at Mole National Park (72.3\%) than at Kainji Lake National Park (50.8\%). Other challenges encountered such as insufficient share of park resources was higher at Mole communities (42.0\%) and less at Kainji Lake (20.5\%). Lack of credit facilities was lower at Mole (41.2\%) than the $48.8 \%$ response at Kainji Lake communities. Difficulty in transporting farm produce to the market was also lower at Mole National Park (34.3\%) than at Kainji Lake National Park (40.1\%). Lack of storage facilities as well as diseases and pest of crops and livestock were lower at Mole National Park with 23.7\% and 24.1\% respectively than at Kainji Lake National Park with 33.3\% and 31.6\% respectively. 
Table 2: Livelihood challenges of adjacent communities of Kainji Lake and Mole National Parks

\begin{tabular}{|c|c|c|c|c|}
\hline \multirow[b]{2}{*}{ Challenges variables } & \multicolumn{2}{|c|}{ Kainji Lake National Park } & \multicolumn{2}{|c|}{ Mole National Park } \\
\hline & $\begin{array}{l}\text { Frequency } \\
\text { (f) }\end{array}$ & $\begin{array}{l}\text { Percentage } \\
(\%)\end{array}$ & $\begin{array}{l}\text { Frequency } \\
\text { (f) }\end{array}$ & $\begin{array}{l}\text { Percentage } \\
(\%)\end{array}$ \\
\hline Reduced land for farming & 114 & 38.4 & 150 & 54.7 \\
\hline Exclusion from resource use & 114 & 38.4 & 142 & 51.8 \\
\hline Crop destruction by wild animals & 195 & 65.7 & 141 & 51.5 \\
\hline Insufficient infrastructural development & 151 & 50.8 & 198 & 72.3 \\
\hline Insufficient share of park resources & 61 & 20.5 & 115 & 42 \\
\hline Lack of credit facilities to trade & 145 & 48.8 & 113 & 41.2 \\
\hline $\begin{array}{l}\text { Difficulty in transporting farm produce to } \\
\text { market }\end{array}$ & 119 & 40.1 & 94 & 34.3 \\
\hline Lack of storage facilities & 99 & 33.3 & 65 & 23.7 \\
\hline Diseases and pest of crops and livestock & 94 & 31.6 & 66 & 24.1 \\
\hline
\end{tabular}

Source: Authors' Fieldwork, 2016

\section{Hypothesis Testing}

The hypothesis that was tested is stated in the null and alternative forms below:

$\mathbf{H}_{\mathbf{0}}$ : There is no significant difference between the challenges encountered at the communities of Kainji Lake and Mole National Parks.

$\mathbf{H}_{\mathbf{a}}$ : There is a significant difference between the challenges encountered at the communities of Kainji Lake and Mole National Parks.

Significance level $(\alpha)$ is $P \leq 0.05$

The Chi-squared test result for the hypothesis stated is presented in Table 3, which indicates that there is a significant difference between the challenges encountered at the communities of both National Parks in attaining their livelihood activities $\left(X^{2}=9.41 ; P=0.002\right)$. This implies that the null hypothesis stated above is rejected and the alternative hypothesis is accepted.

Table 3: Result of the hypothesis Test

\begin{tabular}{|c|c|c|c|c|c|}
\hline Hypothesis & $\begin{array}{l}X^{2} \\
\text { value }\end{array}$ & $\begin{array}{l}\text { Df } \\
n-1\end{array}$ & $\begin{array}{l}P \text { - } \\
\text { value }\end{array}$ & Remark & Decision \\
\hline $\begin{array}{l}\mathrm{H}_{0:} \text { There is no significant difference between Kainji Lake } \\
\text { and Mole communities' perception regarding challenges } \\
\text { encountered in their livelihood activities. } \\
\mathrm{H}_{\mathrm{a}} \text { There is a significant difference between Kainji Lake and } \\
\text { Mole communities' perception regarding challenges } \\
\text { encountered in their livelihood activities. }\end{array}$ & 9.411 & 581 & 0.002 & Significant & $\begin{array}{l}\text { Reject } \mathrm{H}_{\mathrm{o}} \\
\text { and accept } \\
\mathrm{H}_{\mathrm{a}}\end{array}$ \\
\hline
\end{tabular}

\section{Reduction in Access to Farmland}

\section{DISCUSSION}

The economy of the communities adjacent to the two National parks is basically subsistent economy that is dependent on agriculture. This is reflected in the percentage of respondents involved in farming as the main livelihood activity in the communities. This result shows an agrarian community which depends so much on available land for survival. One of the challenges that was mentioned and causing major conflicts with Park management is that of the reducing available land for farming. This finding is supported by the WWF [29] report which shows that more than $95 \%$ of people living around protected areas are dependent on agriculture based activities. Other livelihood activities at the communities included trading, and artisanry. But the trading activities which included buying, reselling and processing of 
farm produce (such as cassava into garri, yam into yam flour) and then selling at the market, were equally affected by limited access to farmland.

In line with traditional norm, the women in the communities did more of trading and other income generating activities while the men were more involved in farming and were allowed to own farmlands. Artisanry comprised mainly blacksmithing and basket weaving which are traditional activities in some communities of Mole National Park. Information obtained during the focused group discussions shows that other activities of respondents at the two communities include gathering of forest products such as firewood, leaves, herbs, spices and other items for household use. Some of the items collected were either used personally or sold to purchase other items needed by respondents. These activities were being hindered by limited access to land.

Firewood which is necessary for cooking and some farm produce processing such as frying and drying of garri were also limited as the residents complained that they were no longer allowed to freely collect the needed items. This finding agreed with that of Busshell and Eagles [30] who recognised the exclusion from forest resource use as one of the major challenges towards ecotourism development.

\section{Impact on farmland and livestock}

A major challenge of communities living adjacent to National Parks is the destruction caused by wild animals to farms and livestock. At Kainji Lake and Mole National Parks, destruction of farmlands by raiding wild animals was a major concern as indicated by more than half of the respondents. This is in consonance with the opinion of Nahonyo [31] who revealed that in Africa, than elsewhere in the world, the average loss caused by wildlife is about $40 \%$ of all planted crops. During the group discussions, participants at Mole National Park emphasized that some animals which tourists are attracted to (such as the elephant), were responsible for sometimes destroying a whole farm. Other animals include baboons which destroy crops and also attack livestock, while the warthog destroys and uproots planted tubers. Lepp [32] found that farmers (of both crops and livestock) are sometimes vulnerable to the same wild animals which attract tourists. It is more frustrating to the farmers that they are neither allowed to kill the animals (due to their importance to ecotourism) nor paid for damages caused by the animals.

\section{Infringement on Culture}

The exclusion of residents from use of forest resources became a major challenge that many of the respondents found difficult to cope with as most of their cultural and traditional rites and livelihood have been built around the use and availability of the natural resources found in the Parks. Communities have been made to understand that they could no longer celebrate or would need to modify some of their festivals especially when they would need to use animals in performing some rites. Many of the houses had thatched roofs; and the fences demarcating households were equally made of woven long grasses and raffia palms. Resources for these were no longer easily accessible.

\section{Other Impacts}

Another major challenge at the two National Parks was insufficient infrastructural development. Information obtained from the participants revealed that infrastructure such as roads, electricity, and potable water were lacking in most of the communities and only a few communities had access to good schools and clinics. These findings concurred with Abdullah et al, [33] who stated that bad roads make transportation difficult for local people especially 
during the harvest season when much of farm produce needs to get to the market. More so, many residents in the communities did not own vehicles and motorcycles and so they had to rely on a few who could convey them and their goods to the market. This has made transportation of people and goods difficult and expensive. The need to make credits and loans available especially among the women who need the money to buy items to sell, as well as the men who need money to farm and also raise livestock is important.

\section{CONCLUSION AND RECOMMENDATIONS}

This study observed that livelihood activities at both National Parks consisted mainly of crop and animal farming activities, and that the adjacent communities were dependent on the natural resources of the National Parks. Challenges to livelihood activities were discovered to be similar at the two National Parks. Some of the major challenges from the communities were the destruction caused by wild animal attack on crops and livestock, reduced access to farmlands, insufficient infrastructural development as it affects roads, electricity and potable water and the negative impact on people's culture.

Based on the findings of this research, it is recommended that local residents in adjacent communities should be trained by the Park Management as tour guides and interpreters so that they can earn money from such ecotourism services provided. Also, alternative livelihood activities which are ecotourism-based such as souvenir making and cultural display should be provided to reduce the challenges encountered by the local residents. Other measures which include compensation for damages caused by wild animals, and collaboration with Nongovernmental Organizations (NGOs) to provide basic infrastructure and training on alternative sources of livelihood are equally recommended. Such NGOs should also provide financial and material support to empower residents.

\section{References}

Scheyvens, R., \& Momsen, J. H. (2008). Tourism and poverty reduction: Issues for small island states. Tourism Geographies, 10(1), 22-41.

Ndenecho, E.0. 2009: Ecological planning and ecotourism development in KimbiGame Reserve, Cameroon. Journal of Human Ecology, 27 (2), 105-113.

Ashley, C., Roe, D., \& Goodwin, H. (2001). Pro-poor tourism strategies: Making tourism work for the poor. Nottingham: Russell Press.

Ishak, M. (2015). Terrestrial protected areas and poverty reduction in Ghana: A case study of the Mole National Park and the Mognori and Murugu communities. Journal of Development Studies, 8(1), 129-192.

Neth, B. (2008). Ecotourism as a tool for sustainable rural community development and natural resource management in The Tonle Sap Biosphere Reserve, Germany. Unidruckerei, University of Kassel.

Ashley, C. (2000). The impacts of tourism on rural livelihoods: Experience in Namibia. Overseas Development Institute (ODI) Working Paper No. 128. London: Overseas Development Institute.

Ijeomah, H. (2012). Impact of tourism on livelihood of communities adjoining eco-destinations in Plateau State, Nigeria. Culture, 6(3), 55-71. Special Issue.

Ashley, C and Hussein, K. (2000). Development methodologies for livelihood impact assessment of the African wildlife foundation in East Africa. Overseas Development Institute, London. Pp 60 in Ijeomah, H. (2012). Impact of tourism on livelihood of communities adjoining eco-destinations in Plateau State, Nigeria. Culture, 6(3), 55-71. Special Issue.

Kamuaro, O. (1996). Ecotourism: suicide or development? Voices from Africa, 6, 59-65.

Maurer, J.L. and Zeigler, A. (1988). Tourism and Indonesian cultural minorities, In: Rossel, P. (ed) Tourism: Manufacturing the Exotic. I.W.G.I.A. Document 61. PP. 6491. Copenhagen. 
Arowosafe, F. C. \& Emmanuel, A. A. (2017). Livelihood Challenges of Adjacent Communities of Selected National Parks in West Africa. Advances in Social Sciences Research Journal, 4(7) 69-78.

Singh, T.V. (1989). The Kulu valley: Impact of tourism development in the mountain area. New Delhi: Himalayan Books.

Timothy, D.J. and Wall, G. (1997). Selling to Tourists: Indonesian Street Vendors. Annals of Tourism Research, $24(2), 322-340$.

Same as 6

Ayodele, I.A. (2002). Essentials of tourism management. Ibadan: El-Shaddai Global Ventures.

Yunis, E. 2004. Sustainable Tourism and Poverty Alleviation. Paper presented at the World Bank ABCDE Conference - Europe on 10 $0^{\text {th }}$ May, 2004, PP. 1-8.

Cezayiri, G. (2004). Urban poverty; Tourism: More than just sight-seeing. Retrieved 30 August, 2004 from http://www.adb.org/document/periodicals/NGOletter

Knoema. (2017). Ghana - Travel and tourism total contribution to GDP. Retrieved January 27, 2017, from https://knoema.com/atlas/Ghana/topics/Tourism/Travel-and-Tourism-Total-Contribution-to-GDP/TotalContribution-to-GDP-percent-share

Ojo, J. S. (2014). Managing tourism for socio-economic development in nigerian local government: A case study of Idanre local government area. Journal of African Studies and Development, 6(2), 29-35.

Akwotugu, M.K. (2004). Community participation in the development of ecotourism: a case study of the Mole National park. (Unpublished M.Phil. thesis). University of Cape Coast, Ghana. 156.

Adeleke, B.O. (2009). Community participation in Conservation: A pathway to tourism development in protected areas. Journal of Research in National Development, 7(1), 116-121.

Bajracharya, S.B., Furley, P.A., and Newton, A.C. (2006). Impacts of community-based conservation on local communities in the Annapurna conservation area, Nepal. Biodiversity and Conservation, 15(8), 2765-2786.

Farooq, S.U., Khan, Z., Ullah, Z., and Shams, M.S. (2012). The impact of tourism on local livelihood: A case study of Galliyat, District Abbotabad. Eur. J. Sci. Res., 68 (1), 43-53.

Asmamaw, D. and Verma, A. (2013). Ecotourism for environmental conservation and community livelihoods, the case of the Bale mountain National park, Ethiopia. Journal of Environmental Science and Water resources, 2(8), 250-259.

Snyman, S. L. (2012): The role of tourism employment in Poverty reduction and community perceptions of conservation and tourism in Southern Africa. Journal of Sustainable Tourism, 20, 395-416

Mole National Park (2015). Mole National Park - The Park. Retrieved January 27, 2017 from

molenationalpark.org.gh/welcome.php

Kuuder, C.W. (2012). Tourism potentials of Mole National Park in Northern Ghana. African Journal of Hospitality, Tourism and Leisure, 2(1), 1-19.

Ijeomah, H. M., Ogogo, A. U. \&Ogbara, D. (2013). Analysis of poaching activities in Kainji Lake National Park of Nigeria. Environment and natural resources research, 3(1), 51-61.

Same as 19

World Wildlife Fund for Nature (WWF) (2001): Improving protected area management. WWF's rapid assessment and prioritization methodology, Forest for Life: Protect, Manage and Restore. Ervin J. (Ed): Key aspects and benefits of management practice: Conference on Wilderness and Large Natural Habitat Areas, May 27-29, Czech Republic.

Bushell, R., \& Eagles, P.F.J. (Eds.). (2007). Tourism and protected areas: Benefits beyond boundaries. London: London $\mathrm{CAB}$ International

Nahonyo, C. (2001). Human-elephant conflict in the Greater Ruaha Ecosystem, Tanzania. PhD Thesis, Canterrbury, U.K., University of Kent.

Lepp, A. (2007). Residents' attitudes towards tourism in Bigodi Village, Uganda. Tourism Management, 28(3), 876885.

Abdullah, S., Abdul Razak, A., and Jaafar, M. (2014). Public tourism infrastructure: challenges in the development and maintenance activities. Universiti Sains Malaysia, 11800 Penang, Malaysia DOI: 10.1051/ published by EDP Sciences, 2014 shsconf/201412010. 